\title{
Juvenile Rheumatoid Arthritis with IgA Deficiency and Appearance with Febrile Episode
}

\author{
Takashi Isobe, MD, Toshio Ito, MD, Junji Matsumoto, MD \\ and Takuo Fujita, MD
}

\begin{abstract}
A 24-year-old female had juvenile rheumatoid arthritis since the age of 3 , with systemic manifestations such as fever, polyarthralgia, micrognathia, splenomegaly, hepatomegaly, lymphadenopathy, subcutaneous nodules, hidden rheumatoid factor of IgG type. Particularly noteworthy is selective IgA deficiency in this patient, with increases in concentration up to $50 \mathrm{mg} / \mathrm{dl}$ in the serum concurrently with the repeated febrile attacks in the clinical course.
\end{abstract}

Key Words: IgA defieiency, Fluctuating $\lg$ A levels after febrile attacks and operations.

Juvenile rheumatoid arthritis (JRA) usually defined based on the onset before age 16, manifests in three or more types, including the systemic type marked by an abrupt beginning with a febrile illness ${ }^{1)}$. JRA is characterized by high fever, chronic iridocyclitis, lymphadenopathy, splenomegaly, monoarthicular onset and hidden rheumatoid factor ${ }^{2)}$. In this report, we present a patient with JRA with a clinical history for 21 years, who provided us an interesting phenomenon regarding serum IgA levels.

\section{MATERIALS AND METHODS}

Serum electrophoresis and immunoelectrophoresis were performed as described previously ${ }^{3}$. Serum immunoglobulins were determined by radial immunodiffusion. Immunoperoxidase stainings were done by a sandwhich technique using specific rabbit antisera for human Ig's, peroxidase-conjugated goat antibody directed against rabbit IgG and the diaminobenzidine reaction.

Mononuclear cells were isolated from heparinized venous blood by Ficoll-Hypaque and then incubated at $37^{\circ} \mathrm{C}$ for 1 hour. Cells were washed with $2 \%$ bovine serum albumin in phospate buffered saline after adjusting to a density of $1-2 \times 10^{7}$ cells per $\mathrm{ml}$ for studies. Sheep erythrocyte rosetteforming cells were done as described previously ${ }^{3)}$. Only rosettes with three or more bound sheep red cells were scored as positive $\mathrm{T}$ cells. Enumerations of the $\mathrm{T} \gamma$ and $\mathrm{T} \mu$ subpopulations in the peripheral blood were performed after formation of rosettes with ox erythrocytes coated with subagglutinating amounts of rabbit IgG purified through DEAE-chromatography (Wattmann DE52) and rabbit IgM purified through Sephadex G-200 followed by affinity column chromatography to exclude aggregated $\operatorname{IgG}$, respectively ${ }^{3)}$. T $\mu$ rosettes. were prepared after overnight incubation of $\mathrm{T}$ cells in $\mathrm{Tc}-199$ supplemented with $20 \%$ fetal calf serum.

B lymphocytes were defined by the presence of intrinsic surface Ig by using immunofluorescent technique with anti IgM. IgA-bearing lymphocytes were defined by the presence of cytoplasmic IgA using immunofluorescent technique after incu-

From The Third Department of Internal Medicine, Kobe University School of Medicine

Received for publication January 21, 1980.

Reprint request to: Takashi Isobe, MD, The Third Department of Internal Medicine, Kobe University School of Medicine, 7-chome Kusunoki-cho, Ikuta-ku, Kobe, 650, Japan. 
bation of the smear films of peripheral lymphocytes with 100 times diluted fluoresceinated antiserum for $\operatorname{Ig} \mathrm{A}$ at $37^{\circ} \mathrm{C}$ for 30 minutes $^{3)}$.

PHA blastogenesis was examined by lymphocytes at a concentration of $5 \times 10^{5}$ / $\mathrm{ml}$ in $10 \%$ fetal calf serum for 48 hours with and without PHA (Difco, $75 \mu \mathrm{g} / 5 \mathrm{ml}$ ). Stimulation index was calculated by the ratio of ${ }^{3} \mathrm{H}$ thymidine incorporation counts in the presence of PHA to those without PHA.

\section{CASE PRESENTATION}

M.O. a 24-year-old female, complained of fever and polyarthralgia, which dated back to the age of 3 . Her family history was not contributory. Laboratory examinations of patient's father, mother and 3 brothers showed normal findings including normal immunoglobulin levels and negative rheumatoid factor. At the age of 8, jaundice lasted for about 3 weeks, associated with fever, long standing polyarthralgia of temporo-mandibular and metacalpophalangeal joints. At the age of 14 and 20, she had the third and fourth attacks of fever and polyarthralgia, which were apparently more severe than before. A synovectomy of the right kness was done at the age of 20 .

On admission in June, 1976, she was found to have micrognathia, lymphadenopathy, hepatomegaly of $3 \mathrm{~cm}$ and splenomegaly of $1 \mathrm{~cm}$ below the costal margin, bilateral joint swellings and X-ray abormalities of the wrists, carpal, phalangeal and hip joints. Her major laboratory data were listed in Table 1. Other data included red cells of 4.56 million, platelets of $10.5 \times 10^{4} / \mathrm{mm}^{3}$, erythrocyte sedimentation rate of $50 \mathrm{~mm} / \mathrm{hr}$, negative intradermal test

Table 1. Major clinical data.

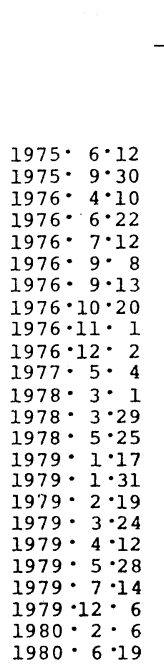

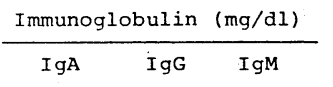

$\frac{\text { Serum protein }(g / d 1)}{\text { TP Alb } \frac{\text { Globulin }}{\alpha_{1} \quad \alpha_{2} \quad \beta \quad \gamma}}$

$\frac{\text { Peripheral blood }}{\text { WBC Lymphocyte }}$

$\begin{array}{rr}1,500 & 140 \\ 987 & 62 \\ 1,620 & 118 \\ 630 & 25 \\ 399 & 58 \\ 588 & 33 \\ 462 & 27 \\ 630 & 42 \\ 462 & 26 \\ 588 & 20 \\ 756 & 46 \\ 1,071 & 62 \\ 924 & 81 \\ 903 & 73 \\ 672 & 62 \\ 609 & 57 \\ 1,260 & 51 \\ 1,323 & 142 \\ 1,134 & 114 \\ 1,092 & 94 \\ 1,420 & 82 \\ 1,806 & 62 \\ 2,226 & 112 \\ 2,226 & 67\end{array}$

$\begin{array}{llllll}5.8 & 3.6 & 0.4 & 0.8 & 0.7 & 0.3 \\ 6.1 & 3.5 & 0.4 & 0.8 & 0.7 & 0.7 \\ 6.0 & 3.6 & 0.4 & 1.0 & 0.8 & 0.3 \\ 6.3 & 3.9 & 0.3 & 0.8 & 0.9 & 0.4 \\ 5.5 & 3.5 & 0.3 & 0.8 & 0.6 & 0.3 \\ 5.6 & 3.7 & 0.3 & 0.6 & 0.7 & 0.3 \\ 5.3 & 3.6 & 0.3 & 0.5 & 0.6 & 0.3 \\ - & - & - & - & - & - \\ 5.5 & 3.7 & 0.3 & 0.6 & 0.6 & 0.3 \\ 5.7 & 3.9 & 0.3 & 0.6 & 0.6 & 0.3 \\ - & - & - & - & - & - \\ 6.2 & 4.2 & 0.2 & 0.4 & 0.6 & 0.8 \\ 6.0 & 4.1 & 0.2 & 0.4 & 0.7 & 0.6 \\ 5.9 & 4.1 & 0.2 & 0.4 & 0.6 & 0.6 \\ 4.8 & 2.7 & 0.4 & 0.5 & 0.4 & 0.8 \\ 6.3 & 3.9 & 0.4 & 0.7 & 0.7 & 0.6 \\ 6.2 & 4.2 & 0.2 & 0.3 & 0.5 & 1.0 \\ 6.0 & 3.8 & 0.3 & 0.3 & 0.5 & 1.2 \\ 6.5 & 3.8 & 0.3 & 0.5 & 0.7 & 1.2 \\ 6.2 & 3.9 & 0.2 & 0.4 & 0.8 & 0.9 \\ 7.5 & 4.5 & 0.3 & 0.5 & 0.7 & 1.5 \\ 7.6 & 4.5 & 0.2 & 0.5 & 0.7 & 1.6 \\ 7.5 & 4.1 & 0.2 & 0.5 & 0.8 & 1.8 \\ 7.5 & 4.4 & 0.3 & 0.5 & 0.7 & 1.6\end{array}$
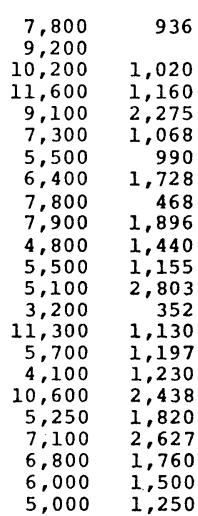

\begin{tabular}{|c|c|c|}
\hline $7+$ & & (a) \\
\hline $3+$ & & (b) \\
\hline $4+$ & & \\
\hline $2+$ & & \\
\hline $2+$ & & \\
\hline $2+$ & & (c) \\
\hline $2+$ & & (d) \\
\hline $3+$ & - & (e) \\
\hline $\begin{array}{l}3+ \\
2+\end{array}$ & & \\
\hline & & \\
\hline \pm & & (f) \\
\hline $6+$ & 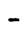 & $(a)(g)$ \\
\hline $4+$ & - & (e) \\
\hline $\begin{array}{l}2+ \\
1+\end{array}$ & & \\
\hline $\begin{array}{l}1+ \\
2+\end{array}$ & - & (h) \\
\hline $3+$ & - & (i) \\
\hline & & \\
\hline $1+$ & - & (a) \\
\hline
\end{tabular}

(a) Episode of arthritis with fever and arthralgia

(b) Synovectomy of knee joint (1975.10.5)

(c) Lymph node biopsy (1976.9.10)

(d) Subcutaneous nodule biopsy $(1976 \cdot 11 \cdot 10)$

(e) Plasma cells $0 \%$ in bone marrow aspirate

(f) Arthroplasty of hip joint $(1978 \cdot 3 \cdot 14)$

(g) Intravascular coagulation syndrome

(h) Transient elevation of GOT and GPT for 2 months

(i) Laparotomy and liver biopsy $(1979 \cdot 5 \cdot 22)$

$\mathrm{Rf}$ : Rheumatoid factor by Latex fixation with native serum 
for PPD, mumps, SK-SD, and positive tests for Candida and DNCB. Anti ds-DNA antibody binding capacity was within normal limits, $\mathrm{C}_{4}$ levels $14 \mathrm{mg} / \mathrm{dl}$, and $\mathrm{C}_{3} \mathrm{~A}$ $17 \mathrm{mg} / \mathrm{dl}$. A lymph node biopsy of the axilla revealed chronic lymphadenitis. Pyroninpositive lymphocytes were abundant in the medullary cord but lymphocytes in the paracortical area were not decreased.

Immunological study of lymphocytes from the lymphnode provided $43.8 \% \mathrm{~T}$ lymphocytes and 63.6\% B lymphocytes. There were only 1 to 2 plasma cells positive for $\operatorname{IgA}$ of a section of the node by immunoperoxidase. In her clinical course, it was noted that her serum IgA levels decreased to the undetectable level as shown in Table 1, along with an salival Ig A level of $2 \mathrm{mg} / \mathrm{dl}$ with a demonstration of secretory piece in her saliva. Biopsies of the subcutaneous nodules in both heals revealed fibrinoid necrosis surrounded by granulomatous tissues with abundant lymphocytes and capillaries. She subsequently had fifth, sixth and seventh episodes of fever and polyarthralgia during the following 2 years, but the general conditions improved in rather a short period of treatment with aspirin. She had a surface replacement arthroplasty of right hip joint on March 14, 1978.

Repeated examinations for rheumatoid factor by Latex fixation test and WaalerRose test in the sera persistently showed negative results. However, the isolated IgG fraction through Sephadex G-200 $(2.5 \times 45$ $\mathrm{cm})$ and DEAE-cellulose column $(2.5 \times 30 \mathrm{~cm})$ from the serum was positive for rheumatoid factor, in contrast to the negative results with isolated serum $\operatorname{IgM}$ as well as whole serum. The result disclosed the presence of hidden rheumatoid factor of IgG type in the serum, after the isolation procedure of immunoglobulins (Figure 1).

The eighth attack was occured on January 3, 1979, when she was suffering from disseminated intravascular coagulation syndrome, associated with fever, generalized petechiae, low platelets of $1.5 \times 10^{4} / \mathrm{mm}^{3}$,
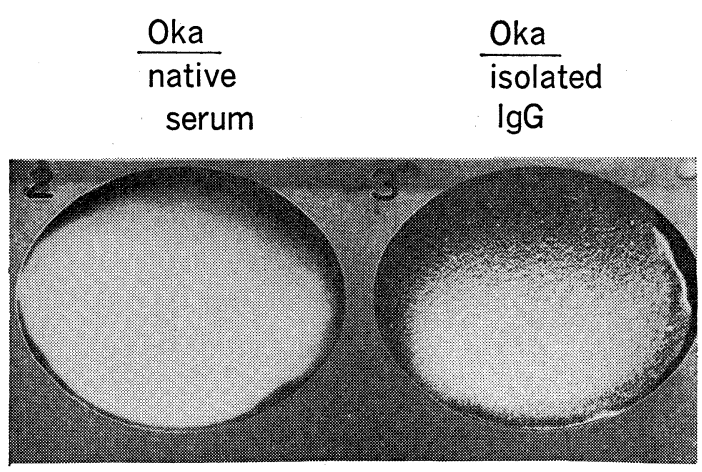

Fig. 1

low plasma fibrinogen of $35 \mathrm{md} / \mathrm{dl}$, increased FDP of $120 \mu \mathrm{g} / \mathrm{ml}$, ESR $5 \mathrm{~mm}$ per hour and CRP +7. Repeated bacteriological cultures from the blood, sputum and urine specimens revealed no abnormalities. Intravenous administration of heparin 20,000 units daily, in combination with antibiotics and prednisolone $15 \mathrm{mg}$ daily appeared to be helpful to eliminate her clinical manifestations in 3 weeks. Interestingly, serum IgA levels increased transiently during these fibrile period, and reduced to become undetectable after improvement.

Table 1 shows pertinent clinical data in this patient during the last 5 years, during which she had 4 epidodes of high fever and arthralgia and 2 operations. It is noted that she had hypogammaglobulinemia. Particularly noteworthy is that serum IgA levels were undetectably low except for brief periods after the episodes of fever and arthralgia along with strongly positive CRP and lymphocytopenia. Table 2 shows an analysis of the pheripheral lymphocytes. Percentage of T cells slightly decreased and PHA blastogenesis of T cell stimulation was shown to be lowered. $\mathrm{T} \mu$ (helper cells) ranged within normal limits, while $\mathrm{T} \gamma$ (suppressor cells) was low in the lymphocyte population. Percentage of $\mathrm{B}$ cells remained almost normal and IgA bearing $\mathrm{B}$ cells ranged $1-3 \%$ of total B cells. In accordance with the presence of IgA-bearing peripheral lymphocytes, this patient seems to have a defect in the 
Table 2. Analysis of the peripheral lymphocytes

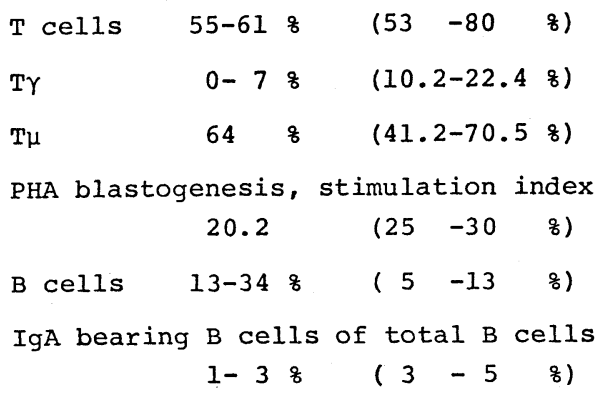

(a) E rosette forming cells with sheep red blood cells

(b) $\mathrm{T}$ cells with IgG-Fc receptor

(c) $\mathrm{T}$ cells with IgM-Fc receptor

(d) Index expressed by a ratio of PHA stimulated and labeled thymidine incorporated lymphocyte count to PHA non-stimulated lymphocyte counts.

(e) Intrinsic surface immunoglobulin positive cells by immunofluorescence.

(f) Surface IgA positive cells with fluorescinated anti $\alpha$-chain.

terminal maturation of their B-lymphocytes into IgA-secreting cells, but such defect in the maturation process is apparently overcome only on the exposure to some stimuli.

\section{DISCUSSION}

Capriciousness is the outstanding feature of JRA. Puzzling signs and symptoms, variable mode of presentation, and several unpredictable patterns of disease course are all hallmarks of this childhood illness ${ }^{1)}$. Among these signs and symptoms, major manifestations of higher frequency in JRA than adult type RA included high grade fever, rash, lymphadenopathy, splenomegaly, hepatomegaly, pericarditis, iridocyclitis, monoarticular onset, leukocytosis and negative rheumatoid factor ${ }^{1}$. The present case begun at the age of 3 and meets these criteria. With reference to the diagnosis of JRA established in the present case, major immunological abnormality of selective $\operatorname{IgA}$ deficiency are to be discussed.

IgA deficiency state is an interesting point as show in Table 1, where serum IgA level is undetectable in the clinical course, especially at the rather inactive stage. On the contrary, serum IgA rose in concentrations up to $50 \mathrm{mg} / \mathrm{dl}$, on occasions presumably after episodes of fever and arthralgia or after operations such as synovectomy or arthropathy. Increase of $\operatorname{IgA}$ is possibly not related to prednisolone therapy, since prednisolone is considered to decrease IgG synthesis ${ }^{5}$. IgA-bearing B lymphocytes are reserved as in Table 2 which is consistent with the data by Waldmann $^{6)}$ in IgA-deficient cases, while plasma cells with $\operatorname{IgA}$ in the cytoplasma in the marrow or nodes are very few. It is assumed that under ordinary circumstances, the patient seems to have a defect in the terminal maturation of $\mathrm{B}$ lymphocytes into $\operatorname{IgA}$ synthesizing cells. Under abnormally stimulated condition, synthesized IgA appears to play some roles in the defense mechanism, along with increase of IgG and IgM.

Selective IgA deficiency is reported to occur in up to $4 \%$ of JRA patients ${ }^{1,7)}$ as opposed to $0.2 \%$ of the control. IgA may not be persistently deficient, with fluctuations at an extremely low level. Although this patient seems to have a defect in the termninal maturation of their B-cells into IgA secreting cells, the defect in the maturation overcome on the exposure to some stimuli such as infections and operations. Fluctuating Ig levels exclude the clinical diagnosis of complete dflicency state of Ig, and may reflect the potential reponse to some stimuli. Repeated examinations are therefore to be in mind in the diagnosis and treatment of patients with connective tissue diseases or lymphoproliferative disorders, regarding Ig levels.

ACKNOWLEDGEMENT: The authors wish to express their gratitude to Drs M Fukase, Y Baba, T Horimatsu, K Mori, N Iwatani, H Ikeuchi, T Minamiji and $\mathrm{R}$ Hirose for their clinical work up.

\section{REFERENCES}

1) Calabro JJ : Still's disease: Juvenile chronic polyarthritis. London, Academic press, 1976,

Jap J Med Vol 20, No 3 (July 1981) 
JRA with IgA deficiency

$\mathrm{p} 1$.

2) Allen, JG, Kunkel HG: Hidden rhevmdtoid factors with specificity for native $\gamma$-globulins. Arch \& Rheum 9: 758-768, 1966.

3) Isobe $T$, Horimatsu $T$, Ikeda $Y$, et al: Macroglobulinemia; its polymorphism of clinical manifestations. Acta haemtol Jap 42: 16, 1079.

4) Moretta L, Mingari MC, Webb SR, et al: Imbalances in $\mathrm{T}$ cell subpopulations associated with immunodeficiency and autoimmune syndromes. Eur J Immunol 7 : 696, 1977.
5) McMillan R, Longmire R, Yelenosky R : The effect of corticosteroids on human IgG synthesis. J Immunol 116: 1592, 1976.

6) Waldmann TA: Disorders of suppressor immnnoregulatory cells in the pathogenesis of immunodeficiency and autoimmunity. Ann Intern Med 88: 226, 1978.

7) Cassidy JT, Burt A: Isolated IgA deficiency in juvenile rheumatoid arthritis. Arthr and Rheum 10: 272, 1967. 